\title{
Study Carrels Re-Examined
}

The data from several investigations of study habits are reviewed. The most common place of study is the student's own residence which has the advantage of being personal space rather than institutional space. Present data on use of study carrels and student reaction to them do not support recommendations for substantial increases in carrel facilities.

$\mathrm{T}$ HERE SEEMS TO BE disagreement between the empirical data about study carrels and the recommendations being made concerning them. There are articles, pamphlets, and books that maintain that students like study carrels, but data from surveys of student opinion and behavior do not appear to support this view.

Probably the most comprehensive investigation of the study habits of American college students was undertaken in the 1950's at four New England colleges -Amherst, Smith, Mount Holyoke, and the University of Massachusetts-directed by a committee of faculty and staff from each of the colleges. ${ }^{1} \mathrm{~A}$ variety of methods was used, including questionnaires, interviews, direct observation, and study diaries. Student replies showed a preference for small study spaces with an antipathy toward large open reading rooms. However, when students were asked specifically how often they would use private library

${ }^{1}$ S. M. Stoke, et al., Student Reactions to Study Facilities (Amherst: Committee on Cooperation, 1960).

Dr. Sommer is Acting Chairman, Department of Psychology, University of Calif., Davis and Mrs. Peterson is a Fellow at the Eselin Institute, Big Sur, Calif. This research was supported in part by a grant from the U.S. Office of Education, Department of Health, Education, and Welfare. carrels, the replies of the 353 students were as follows:

95. How often would you study working in a private carrel (a cubicle with desk and bookshelf) in the library building?

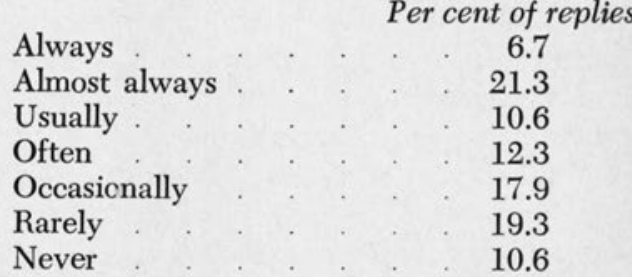

These figures indicate that half the students would use the carrels occasionally or less.

A Study on Studying summarizes the results of a survey administered to seven hundred students at six California junior colleges. $^{2}$ These students were asked specifically for their opinions of study carrels, and the replies were as follows:

Do you want to study in a carrel?

Per cent of replies

Extremely desirable

Very desirable . . 14

Somewhat desirable . 23

Neutral . . 26

Somewhat undesirable . 13

Very undesirable $\quad 6$

Extremely undesirable $\quad 4$

${ }^{2}$ Community College Planning Center, A Study on Studying (Stanford: School Planning Laboratory, n.d.). 
Again, half the students were neutral or disinterested in the use of study carrels. There was no difference between the replies of 264 students on a campus with carrel space available and 405 students on campuses without carrel space.

Bricks and Mortarboards, published in 1964 by Educational Facilities Laboratories, describes the situation at Chicago Teachers' College-North. This is a new campus with private study areas, called Q-spaces or Quest spaces, which have become the trademark of the architectural firm Perkins and Will. Several wide corridors are lined by two hundred Q-spaces which, when equipped with lockers, lamps, chairs, and desks, cost about $\$ 175$ each. Published reports indicate that these study carrels are underutilized, at least in terms of the planners' goals. ${ }^{3}$

A recent survey at the University of California, Davis, ${ }^{4}$ of preferences for library spaces showed that half the students preferred the reading rooms to stacks or carrel areas. The replies showed some fascinating spatial needs, probably related to personality and social factors. There are some students who need the presence of others to maintain their attention. This may not be true when the student is vitally interested in the material, but since a great deal of studying involves material of minimal interest, the importance of, to use the student's own phrase, "a studious atmosphere," seems a relevant consideration.

One salient fact omitted thus far concerns the percentage of study actually done in each kind of location. The New England study disclosed that between 55 and 78 per cent of all studying took place in the students' own rooms. Study diaries in the California junior college survey showed close to 80 per cent of

\footnotetext{
${ }^{3}$ Mel Elfin, "Classrooms" in Bricks and Mortarboards (New York: Educational Facilities Laboratories, 1964).

'R. Sommer, "Ecology of Privacy," The Library Quarterly, XXXVI (July, 1966), 234-48.
}

studying being done in the students' own residences. Study dairies maintained by students at the University of California, Davis, also show 80 per cent of the studying being done in the students' own residences. In another study the authors asked students to design ideal study areas for themselves. This was an openended question with the student able to include anything he wanted. The answers pictured an area that was soundproofed, well-lit, containing a large desk with considerable writing surface, comfortable chairs, study lamp, the student being the sole occupant of the room, etc. No students mentioned individual study carrels in the library as their "ideal study area." Libraries obviously cannot realistically aim at providing such "ideal" study places for students, since economic as well as space considerations enter the picture, but the evidence does seem to indicate the disagreement between the ideal study area as the student sees it and the traditional library study carrel; as well as the similarity between the ideal study area and the student's own room, if it were properly designed and furnished.

To build large study halls equipped with carrels and partitions, capable of seating one-third of school enrollment at any one time, if current recommendations are heeded, ${ }^{5}$ is an expensive solution that provides an impersonal institutional environment rather than personal space. The characteristics of institutional space have been described as large, cold, impersonal, not owned by any individual, over-concentrated rather than overcrowded, without opportunity for shielded conversation and providing barriers without shelter, isolation without privacy, and concentration without cohesion. ${ }^{6}$

${ }^{5}$ R. E. Ellsworth and H. D. Wagener, The School Library (New York: Educational Facilities Laboratories, 1963).

${ }^{\circ} \mathrm{R}$. Sommer, "Alien Buildings," Arts and Architecture, LXXXIII (April 1966), 18-19. 
Results of interviews in dormitories and those conducted in college libraries have presented surprising contrasts. In one study the students interviewed in libraries felt more privacy in the library than at home. When students were interviewed at home, however, they felt that their rooms were much more private than the library. It would appear that people who want the psychological isolation provided by an institutional environment will go to the library to study, while those who prefer an individual territory, perhaps shared by a roommate, will remain in their rooms. The necessity for providing a variety of study spaces, rather than relying exclusively on study halls, carrels, or stack areas becomes apparent, particularly if one considers that the vast majority of studying takes place in the students' own residences. The money going into study halls has to come from somewhere else. Dormitory planning committees on occasion have had to battle to preserve bedroom size against incursions by advocates of more lounges, recreational rooms, or study halls. Ideally it would be desirable to provide separate study halls in dormitories for students who want them, but, except at a very few well-endowed institutions, the square footage going into a carrel room has to come out of some other area.

This article is not intended to discourage the provision of study carrels in libraries. Rapid changes in educational hardware as well as new demands for individual research make it incumbent upon librarians to question current library design and furnishings. It has not yet been proven, however, that study carrels represent a sufficiently great advance in library furnishings to occupy, as has been recommended, 60 per cent of library study space. Since present data indicate that students spend most of their time studying in their rooms, which have the advantage of privacy as well as possibilities for relaxation, move- ment, and "being oneself," perhaps what are needed are institutional arrangements that allow students more time for studying at home. Those who want to transfer the university model to the secondary school might give some thought to reducing contact hours in high school to the university average of $12-15$ per week. Students who lack study facilities at home could have them provided somewhere in the school building, perhaps in classrooms divided with movable partitions. Those students who possess adequate study space at home should not be required to spend unnecessary hours in an institutional environment unless they choose to do so.

During visits to dormitories in ten different campuses, the authors found that the most common place for the student to be at the moment of the interview was on his bed. The bed was preferred for relaxation, conversation, and light reading. The study desk was used for hard studying, particularly when note-taking was involved, with the floor used as an auxiliary storage and work area. When unoccupied classrooms are used as study places, it is common to find students heading first to the instructor's desk which contains the largest writing surface and, if that is taken, to spread their belongings on several adjacent chairs to provide more working area and an enlarged personal territory.

It may be that individual study as we know it is less efficient as a learning technique than a student interacting with a teaching machine, controllable TV tapes, or group discussion methods. The problem is one of learning, the student acquiring knowledge and skills that he did not possess before, rather than studying, teaching, or the combination of the two we call education. One of the authors recently spent a week observing study habits at a marine field station where twenty-five undergraduates were enrolled in a summer course. Although

(Continued on page 272) 
made of the tabulation. For example, it suggests one possible answer to a problem which has bothered many librarians who allocate to departments: why have some departments, over the years, consistently not spent the money allotted to them? A frequent answer has been "departmental negligence," but it may sometimes be-as Table 3 shows-that not many books having relevance to their work have been published each year.

The technique is of course not infallible, but if it fails as an argument to controllers of the purse, then the tabula- tions-number and cost of books-could at least be helpful as two factors in an allocation formula. In this situation, the tabulation could be converted to percentages as in Table 4, and the percentages used as scores. At any rate, it appears clear that such tabulations as these, drawn from $B P R$-or in similar ways from other listings-can serve as one more device to aid library management in the ever-recurrent and knotty problem of determining appropriate book funds and their allocations.

\section{CARRELS ...}

(Continued from page 265)

the students spent ten hours a day or more listening to lectures, participating in seminars, away on field trips, or working in the laboratory, there was little formal studying. Library facilities were practically non-existent, and the students were so worn out learning that they had no time for studying. They considered this program a tremendous learning experience, which they attributed to the availability and proximity of resource people and living in a total marine environment. This was an instance where, to use Marshall McLuhan's ${ }^{7}$ apt phrase, environment becomes information with the emphasis on discovery rather than instruction. The students did not read in the context of an environment but explored the environment itself using

\footnotetext{
${ }^{7}$ Marshall McLuhan, Understanding Media: The Extensions of Man (New York: McGraw-Hill, 1965).
}

all the senses and various tools which became extensions of themselves.

In this article the authors are less concerned with this educational philosophy than in making clear the distinction between studying and learning. They question the assumption, made by some, that new trends toward individual lèarning require the sort of study spaces provided by carrels. To be sure, there is no contrary evidence, but the unclarity of the situation does seem to warrant serious exploration of various methods of learning without unnecessary assumptions about the prerequisites for learning. Clearly a variety of study spaces is required to meet the needs of extroverts as well as introverts, lone studiers as well as group studiers, people who like to type as well as those who want to read in easy chairs. Existing data do not appear to justify placing as much emphasis upon individual study carrels as it is, in some quarters, currently receiving. 